\title{
Morphology and systematic position of Tryblidium canadense Whiteaves, 1884 (Mollusca) from the Silurian of North America
}

JOHN S. PEEL

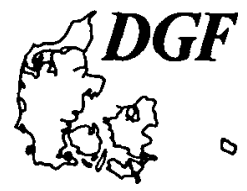

\begin{abstract}
Peel, J. S.: Morphology and systematic position of Tryblidium Canadense Whiteaves, 1884 (Mollusca) from the Silurian of North America. Bull. geol. Soc. Denmark, vol. 38, pp. 43-51. Copenhagen, April 25th, 1990. https://doi.org/10.37570/bgsd-1990-38-04

The nomenclative history of Tryblidium canadense Whiteaves, 1884, a large, oval, univalved mollusc originally described from the Silurian Guelph Formation of Ontario, is reviewed. Following comparison to Archinacella Ulrich \& Scofield, 1897, in which genus it has generally been placed for almost a century, Whiteaves' species is redescribed and assigned to a new gastropod genus, Guelphinacella.
\end{abstract}

John S. Peel, Geological Survey of Greenland, Øster Voldgade 10, 1350 Copenhagen K, Denmark. February 10th, 1989.

Whiteaves (1884) described a single internal mould of a large $(45 \mathrm{~mm})$, oval, univalved mollusc from the Guelph Formation (Silurian) of Hespeler, Ontario, Canada as Tryblidium Canadense (Fig. 1). Uncertainty surrounding its systematic position developed immediately when Lindström (1884) questioned the assignment to the genus Tryblidium Lindström, 1880. On the basis of Whiteaves' $(1884$, pl. 5, figs 1, 1a) illustration, Lindström (1884, p.54) interpreted a thin, continuous, oval band on the dorsal surface as a muscle scar denoting a type of musculature quite different from the discrete paired muscle scars of his earlier described Swedish genus (Fig. 2). Lindström also commented that the two oval depressions illustrated in Whiteaves' figure were quite unlike any structure known in Tryblidium. Whiteaves (1884, pp. 31-32) made no direct reference to either the thin continuous band on the dorsum or the depressions under the apex in his original description, although he observed that "muscular impressions were not satisfactorily known".

Whiteaves returned to the fauna of the Guelph Formation in 1895 , prompted by a general availability of new material and the publication of the monograph of the large Silurian gastropod fauna from Gotland, Sweden, by Lindström (1884). He re-described and re-illustrated the then still unique specimen of Tryblidium Canadense, for the first time discussing the depression located on the sub-apical wall. He commented that the structure seemed to be a single continuous muscular impression and not two separate depressions, as suggested by Lindström (1884), although he did not refer directly to the latter's description. He made no reference to the thin dorsal band which Lindström (1884) had considered to be a muscle scar.

Whiteaves (1895) questioned his own earlier interpretation of the sub-apical depression as a muscle scar, making the astute observation that muscle scars would be expected to be preserved as depressions on the shell interior, hence as elevations on the internal mould. In the holotype of T. Canadense, the sub-apical structure is preserved as a depression on the internal mould, corresponding to an elevation on the shell interior of the living mollusc. In the absence of material other than the holotype, and therefore of more definite information concerning musculature, Whiteaves concluded that interpretation of the sub-apical depression as a muscle scar justified re-assignment of the Guelph species to $\mathrm{Ca}$ pulus Montfort, 1810 . In prefering this assignment, he noted that Tryblidium was considered by Lindström (1884) and contemporary workers to be a patellid gastropod. Studies initiated by Wenz (1940) and Knight (1952), which culminated with the discovery and description of the living Neopilina Lemche, 1957 (Lemche \& Wingstrand, 1959; Wingstrand, 1985), indicated that 

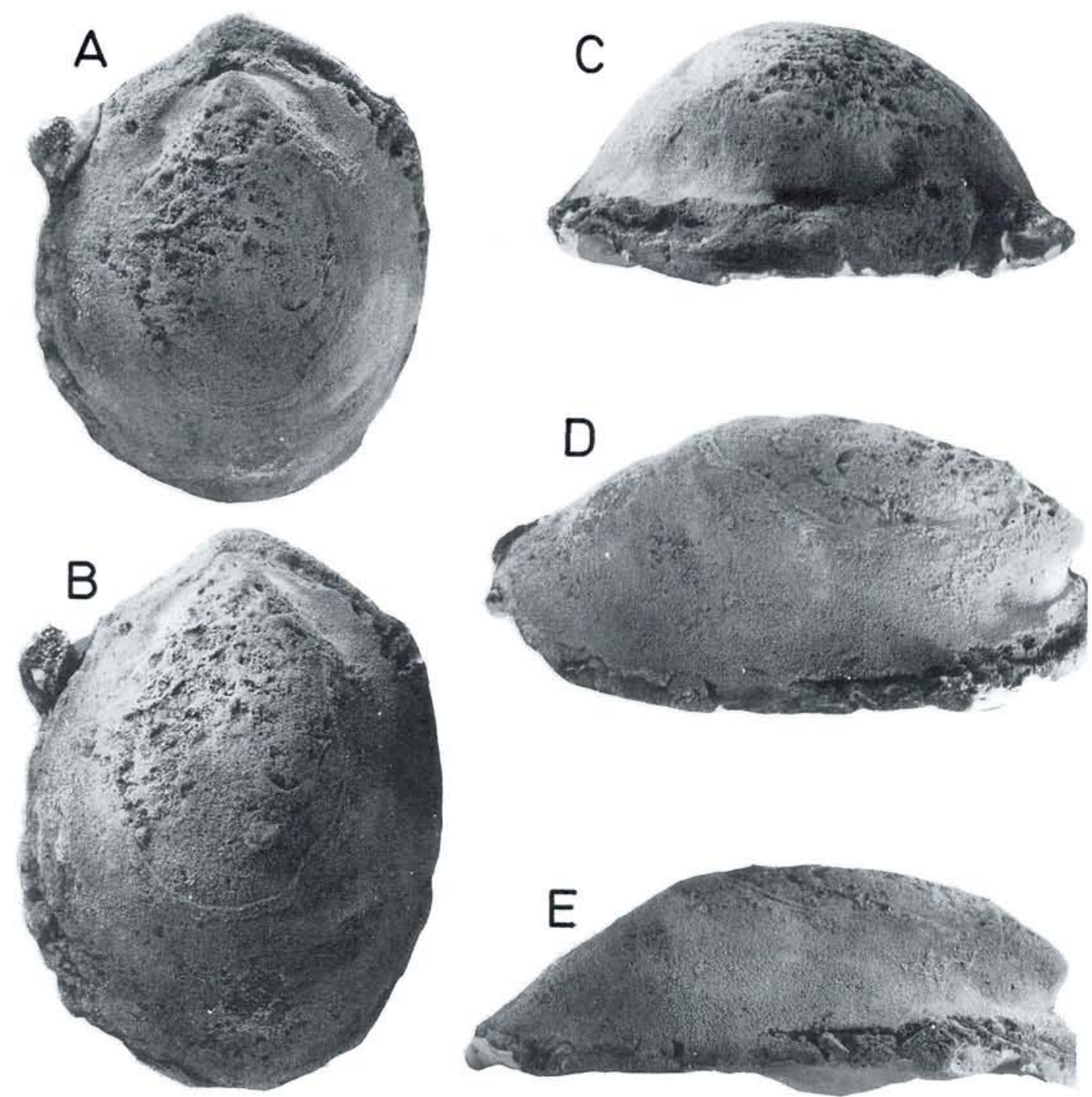

Fig. 1. Guelphinacella canadense (Whiteaves, 1884). Specimen GSC 2907 in the collections of the Geological Survey of Canada, Ottawa, Guelph Formation, Silurian, Ontario, Canada, internal mould of holotype of the type species, X 1.7. A, oblique dorsal view showing the prominent sub-apical depression on the internal mould, representing a thickening on the shell interior. B. dorsal view, note the continuous band on the mid-dorsal region, preserved on the right and abapical surfaces. C, adapical view to show the lateral cross- section. D, oblique lateral view showing the dorsal band and sub-apical depression. E, lateral view showing the longitudinal
cross-section.

Tryblidium is not a gastropod, but a member of the class of untorted molluses called Monoplacophora.

The name Capulus has been widely used in older literature concerning Lower Palaeozoic gastropods, principally in connection with members of the Superfamily Platyceratacea Hall, 1859. The type species, Capulus hungaricus is extant (Wenz, 1938-44).

Ulrich \& Scofield (1897, p. 825) appear to have relied heavily on the interpretation presented by Lindström (1884) in considering Tryblidium Canadense to be "an undoubted member of our new genus Archinacella." This genus, with type species Archinacella powersi Ulrich \& Scofield, 1897 from the Middle Ordovician of Wisconsin (Figs 3 , 4), was considered to closely resemble Tryblidium but to be distinguished by the muscle scar being in the form of a continuous band on the dorsum. 
Fig. 2. Pilina cheyennica Peel, 1977. Specimen YPM 74 in the collections of Yale Peabody Museum, Keel Member of the Chimneyhill Limestone, latest Ordovician, Lawrence, near Ada, Oklahoma, U.S.A. A, silicon rubber impression simulating the shell in apertural view; note the reflexed brim and discrete muscle scars on the interior, $\times 1.8$, oblique apico-lateral view of internal mould showing the raised mould of the protoconch and the large adapical pair of muscle scars, $\times 1 . \mathrm{C}$, dorsal view showing paired muscle scars. $\times 1.5$. At the time of the comparison of Tryblidium and Archinacella with Guelphinacella canadense by Whiteaves (1884, 1895), Lindström (1884) and Ulrich \& Scofield (1897), the genus Pilina Koken, 1925 was not delimited from Tryblidium Lindström, 1880. Many early assignments to the genus Tryblidium consist of species which are morphologically closer to Pilina, as typified by its type species Tryblidium unguis Lindström, 1880, than to Tryblidium sensu stricto, as typified by its type species Tryblidium reticulatum Lindström, 1884.
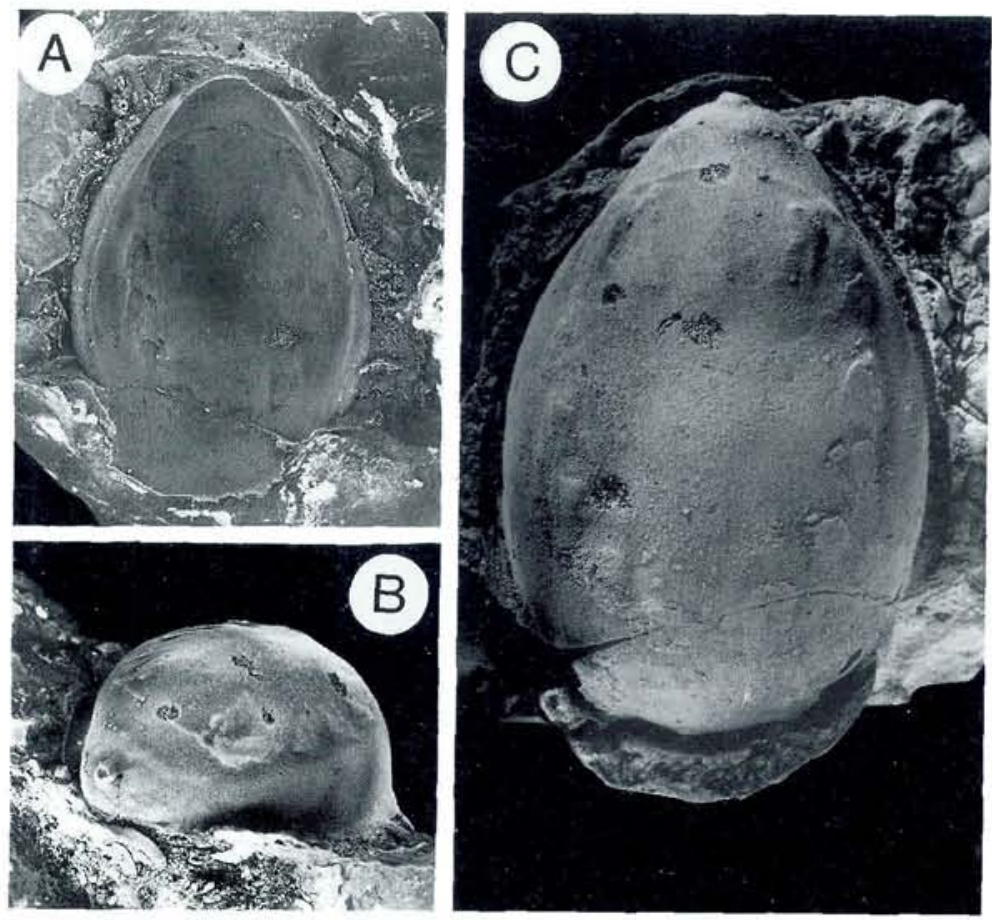

It should be noted, however, that Ulrich \& Scofield (1897) considered Tryblidium unguis Lindström 1880 to be the type species of Tryblidium. Knight (1941) noted that $T$. reticulatum Lindström, 1880 was designated as type species by Miller (1889). Tryblidium unguis, which more closely resembles the Guelph species in general form of the shell, is type species of Pilina Koken 1925.

Ulrich \& Scofield (1897) described muscle scars in $A$. powersi noting, in addition to the dorsal ring, a pair of so-called rostral scars at the apex, with in the dorsal ring, and a pair of anterolateral scars occurring outside of the dorsal muscle scar ring, below and to each side of the apex. Concerning Archinacella, they stated (Ulrich \& Scofield, 1897, p. 828, footnote): "We omitted from the generic diagnosis one feature that ought perhaps to have been included, namely, a pair of scars (? muscular) occurring one on each side of the apex. They lie on the outside of the usual muscular band and have been observed in two species, A. powersi and A. (Tryblidium) canadensis Whiteaves. The latter...has these scars more strongly impressed (in the cast) and further forward than they are in A. powersi." In the accompanying figure (Ulrich \& Scofield, 1897, fig. 1 , which is taken from pl. 61, figs $3-5$ ), the pair of supposed scars in $A$. powersi is denoted by the letter B. In commenting that the structures are impressed on the internal mould, Ulrich \& Scofield leave no doubt that they are discussing the sub-apical depression of Archinacella canadensis (Whiteaves, 1884). Ulrich \& Scofield considered two depressions to be present in A. canadensis, and not a single, continuous depression as reported by Whiteaves (1895).

Whiteaves (1906) noted the assignment by Ulrich \& Scofield (1897) of Tryblidium Canadense to Archinacella without comment.

Knight (1941, pp. 44-45) redescribed the type and apparently only known specimen of Archinacella powersi presenting an interpretation of muscle scars quite different from that originally proposed by Ulrich \& Scofield (1897). He dismissed the supposed antero-lateral scars as "simply slight spots of seemingly fortuitous ferruginous stain" within the area of the band-like muscle scar 


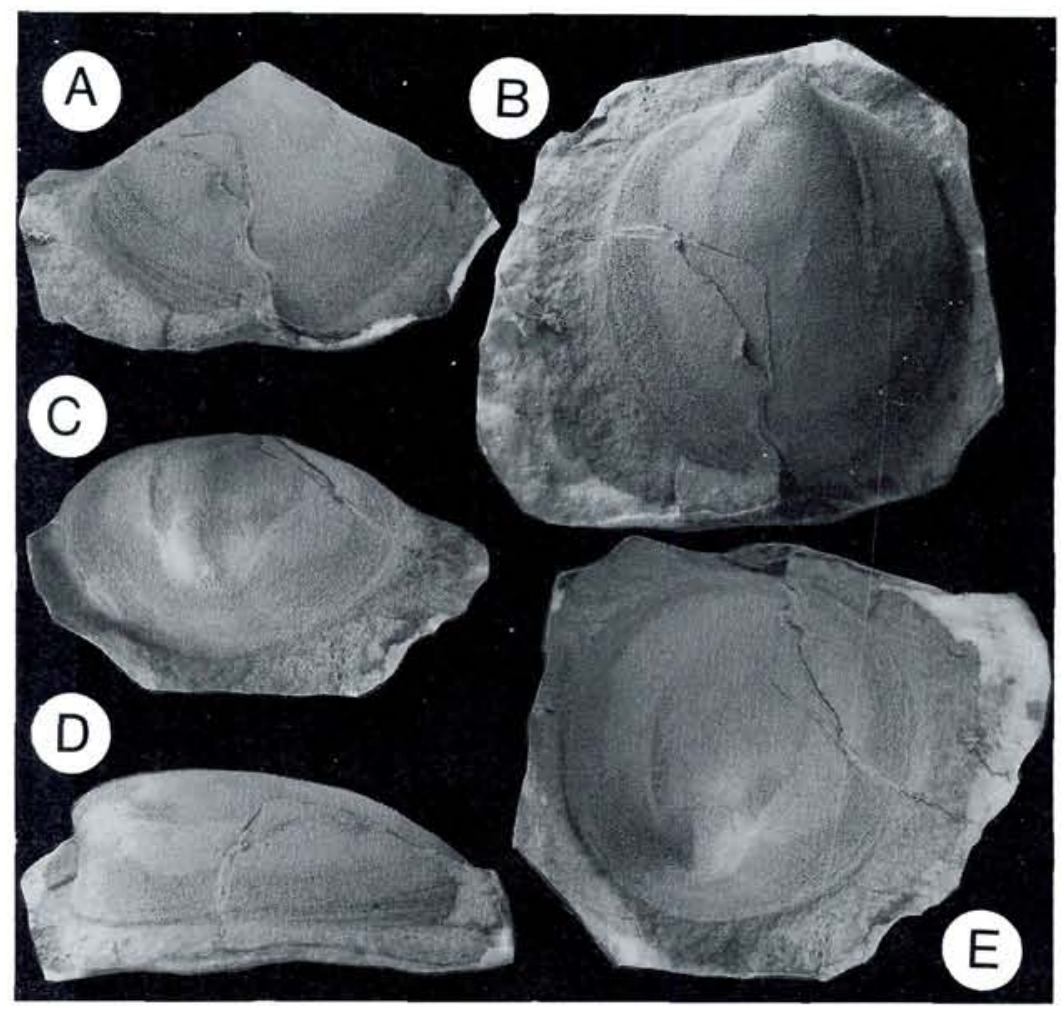

Fig. 3. Archinacella powersi Ulrich \& Scofield, 1897. Specimen number USNM 135949 in the collections of the U.S. Natural History Museum, Washington D.C., Platteville Limestone, Middle Ordovician, Beloit, Wisconsin, U.S.A., latex impression of external mould of the holotype, $\times 1.5$. Note the dorsal band representing the muscle scar which has been superimposed on the external mould during diagenesis. A, abapicodorsal view; $\mathrm{B}$, dorsal view; $\mathrm{C}, \mathrm{E}$, oblique apico-dorsal views; $\mathrm{D}$, lateral view.

which he considered to be much wider than originally suggested by Ulrich \& Scofield (1897). In so doing, he rejected one of the supposed principal points of similarity between Whiteaves' species and the type species of Archinacella, namely the equivalence of the antero-lateral muscle scars of the latter species with the sub-apical depression of the internal mould of Archinacella canadensis. Knight \& Yochelson (1960, fig. 50) apparently supported Knight (1941) in his dismissal of the supposed antero-lateral scars in A. powersi, although the band-like muscle scar was not considered to be as wide as Knight had suggested.

Ulrich \& Scofield (1897) seemingly accepted the interpretation of Lindström (1884) that the circular dorsal band indicated in Whiteaves' (1884, 1895) illustrations of Archinacella canadensis was a muscle scar comparable to that recorded in A. powersi. Peel (1977, p. 120) dismissed the band as "almost certainly an accident of preservation resulting from slight weathering or solution of the coarsely preserved internal mould." In so doing, he broke the remaining connection with Archinacella and emphasised the uncertain generic status of Whiteaves' species.

The natural conclusion of the preceding discussion is that Tryblidium Canadense Whiteaves, 1884 can not be assigned to any one of the three genera to which it has been assigned during its history. It is here described as a new genus, Guelphinacella and referred to the Class Gastropoda, following comparison with Archinacella.

\section{Systematic palaeontology}

Guelphinacella n. gen.

Type species. - Tryblidium Canadense Whiteaves, 1884.

Diagnosis. - Large, ovoid univalve mollusc with dumb-bell shaped thickening of the shell interior under the slightly overhanging apex; the thickening of the shell producing a corresponding depression on the mould of the shell interior. 
Discussion. - The type and only known species of Guelphinacella is known from two internal moulds, both of which show the diagnostic dumbbell shaped depression below the apex. Characters of the shell exterior and ornamentation are not known. The generic name is an arbitrary combination of the classic locality, Guelph, and the name of the morphologically similar Archinacella, to which Whiteaves' species has traditionally been assigned.

\section{Guelphinacella canadense (Whiteaves, 1884)}

Fig. 1

1884. Tryblidium Canadense Whiteaves, p. 31, pl. 5, figs 1, 1a

1895. Capulus Canadensis; Whiteaves, p. 69, pl. 11, fig. 1

1897. Archinacella canadensis; Ulrich \& Scofield, p. 825

1906. Archinacella Canadensis; Whiteaves, p. 330

1977. Archinacella canadense; Peel, p. 118

Holotype. - Geological Survey of Canada, Ottawa, an internal mould carrying specimen number GSC 2907 , collected by T. C. Weston, 1867 , from the Guelph Formation (Silurian) at Hespeler, Ontario, Canada.

Other material. - A fragment of the apex of an internal mould showing the sub-apical depression, from local Silurian dolomites preserved in Milwaukee Public Museum.

Description. - A species of Guelphinacella in which the large ovoid dorsal shell has a length: width ratio of $4: 3$. The dorsal surface of the internal mould is rather uniformly convex both in transverse section (Fig. 1C) and in lateral view between the slightly overhanging, pointed apex and the abapical margin (Fig. 1E). The height of the shell, in lateral view, is approximately one quarter of its length. The sub-apical wall is short, concave on the internal mould (Fig. 1D, E), but the concavity is probably accentuated by the subapical depression. The apertural margins are unknown, but seemingly approximately planar; abapical and lateral walls of the internal mould are somewhat flattened peripherally. The ornamentation, structure and thickness of the shell are not known.
A thickening of the shell interior produces a corresponding sub-apical depression on the internal mould. The depression is dumb-bell shaped, with sub-circular, deepened, lateral extremities joined by a narrower band passing below the apex. In Fig. 1A, the deepest part of the lateral extremities and the sharp lower edge of the sub-apical depression are darkened by shadow. Muscle scars are not certainly known, although a narrow dorsal band on the 3 internal mould may be a muscle scar.

Discussion. - In general morphology, Guelphinacella canadense most closely resembles large specimens of Pilina unguis (Lindström, 1880) from the Silurian of Gotland. Muscle scars in this species are well described by Lindström (1884) and Lemche \& Wingstrand (1959). By virtue of their close similarity to the musculature of Neopilina (Lemche \& Wingstrand, 1959; Wingstrand, 1985), these muscle scars indicate that Pilina, and the closely similar Tryblidium, were undoubtedly monoplacophorans (Fig. 2). Neither $P$. unguis nor Tryblidium reticulatum (Lindström, 1880), the two common Gotland monoplacophorans, show any structure comparable to the sub-apical thickening of $G$. canadense.

Few molluscs of similar form to Guelphinacella canadense are yet described from the Silurian of North America. Peel (1977) noted a possible Pilina from the Lower Silurian Brassfield Formation of Ohio, together with poorly preserved, undescribed internal moulds from local Silurian dolomites preserved in the Greene Paleontological Museum, University of Wisconsin at Milwaukee. Pilina also occurs in the Lower Silurian of eastern North Greenland (Geological Survey of Greenland collections, unpublished observation).

Two Silurian species of Tryblidium have been described from the North American Arctic by Poulsen (1974) and Boucot (1975), respectively, but neither closely resembles $G$. canadense. Boucot dismissed an earlier reported occurrence of Tryblidium from Gaspé (Northrop, 1939).

Guelphinacella canadense resembles Pilina cheyennica Peel, 1977 from strata of latest Ordovician age (Fig. 2). This species has steeper lateral walls, lacks the sub-apical depression on the internal mould and has a well developed apical protruberance, interpreted as part of the pro- 
toconch, also visible on the internal mould. Multiple muscle scars are well known in $P$. cheyennica and are essentially identical to those described in $P$. unguis from Gotland. Undisputed muscle scars are not known in $G$. canadense, nor in any of the other North American Silurian species noted above.

Guelphinacella canadense resembles Archaeopraga pinnaeformis (Perner, 1903) described by Horný (1963a) from the Upper Silurian of Bohemia. The latter is slightly less rounded anteriorly, with a vertical rather than concave sub-apical wall. Archaeopraga lacks the sub-apical structure characeristic of $G$. canadense and is itself characterised by a single pair of laterally disposed muscle scars (Horný, 1963a).

Guelphinacella canadense differs from Archinacella powersi in having an essentially planar aperture, while the aperture is arched in lateral view (Fig. 4) in the latter species. The apex in $A$. powersi is also more highly elevated above the aperture, but this could be partly a function of its smaller size.

\section{Internal structures of Guelphinacella}

The dorsal band. - The irregular dorsal band in the holotype which Lindström (1884) and Ulrich \& Scofield (1897) interpreted as a muscle scar was considered by Peel (1977) to be probably an accident of preservation. It is now felt that evidence to support interpretation as a muscle scar is stronger than previously supposed but still inconclusive. The band is continuous from near the apex on the right side (in Fig. 1B) around the abapical margin; it is absent from the area to the left of the apex where the internal mould, however, is weathered. The band is not preserved in the immediate vicinity of the apex and it can not be determined if it was continuous, passing below the apex or abapically of the apex on the dorsal surface. Neither is it possible to determine if the band terminated on either side of the apex, in a manner similar to the presently preserved limit on the right side. In lateral view (Fig. 1D, E) the band is seen to be shallowly billowing and slightly down-turned at its preserved adapical termination.

The band is raised on the internal mould, as expected for the mould of a muscle scar; in its general location it also compares well with the preserved muscle scar in Archinacella powersi (Fig. 4). The band is distinguished from the muscle scar of $A$. powersi by being continuous around the the abapical margin; in the latter species the muscle scar is $U$-shaped in dorsal view, with the $\mathrm{U}$ opening toward the abapical margin, although weak structures are visible between the two prongs of the $U$ (Figs 3, 4). It should be noted, however, that Horný (1963b) included within Archinacella species in which the muscle scar was continuous around the abapical margin.

The sub-apical thickening. - This structure is considered characteristic of Guelphinacella and is not described from other Palaeozoic cap-shaped shells. It can be loosely compared in terms of position with the shelf-like parietal thickening formed within the aperture of some Palaeozoic bellerophontiform molluscs assigned to the Subfamily Carinaropsinae Ulrich \& Scofield, 1897 by Knight et al. (1960, p. I180). The latter, however, are isostrophically coiled through several whorls, with the parietal deposits commonly much more fully developed than the sub-apical thickening of Guelphinacella. Parietal deposits are found in many helically coiled gastropods but are not described in monoplacophorans such as Pilina. Indeed, Harper \& Rollins (1982) considered the presence of parietal deposits to be a reliable indicator of gastropod affinity in the course of their discussion of the systematic position of the bellerophontiform molluscs.

The shelf-like parietal thickening in carinaropsinids is reminiscent of a similar lamella within the aperture of the living Crepidula Lamarck, 1799. Although anisostrophically coiled, the rate of whorl expansion in species of Crepidula is so great as to produce an elongate shell with similar proportions to Guelphinacella, but still noticably anisomorphic (the familiar 'slipper- limpet', Crepidula fornicata Linné, 1758). The inner lamella supports the internal organs within the widely expanded apertural region of Crepidula and can be ascribed a similar role in some carinaropsinids. The sub-apical thickening in Guelphinacella is clearly too small to have served an identical function but may have provided some measure of support in the apical region; its function is otherwise unknown.

A sub-apical thickening of the type character- 


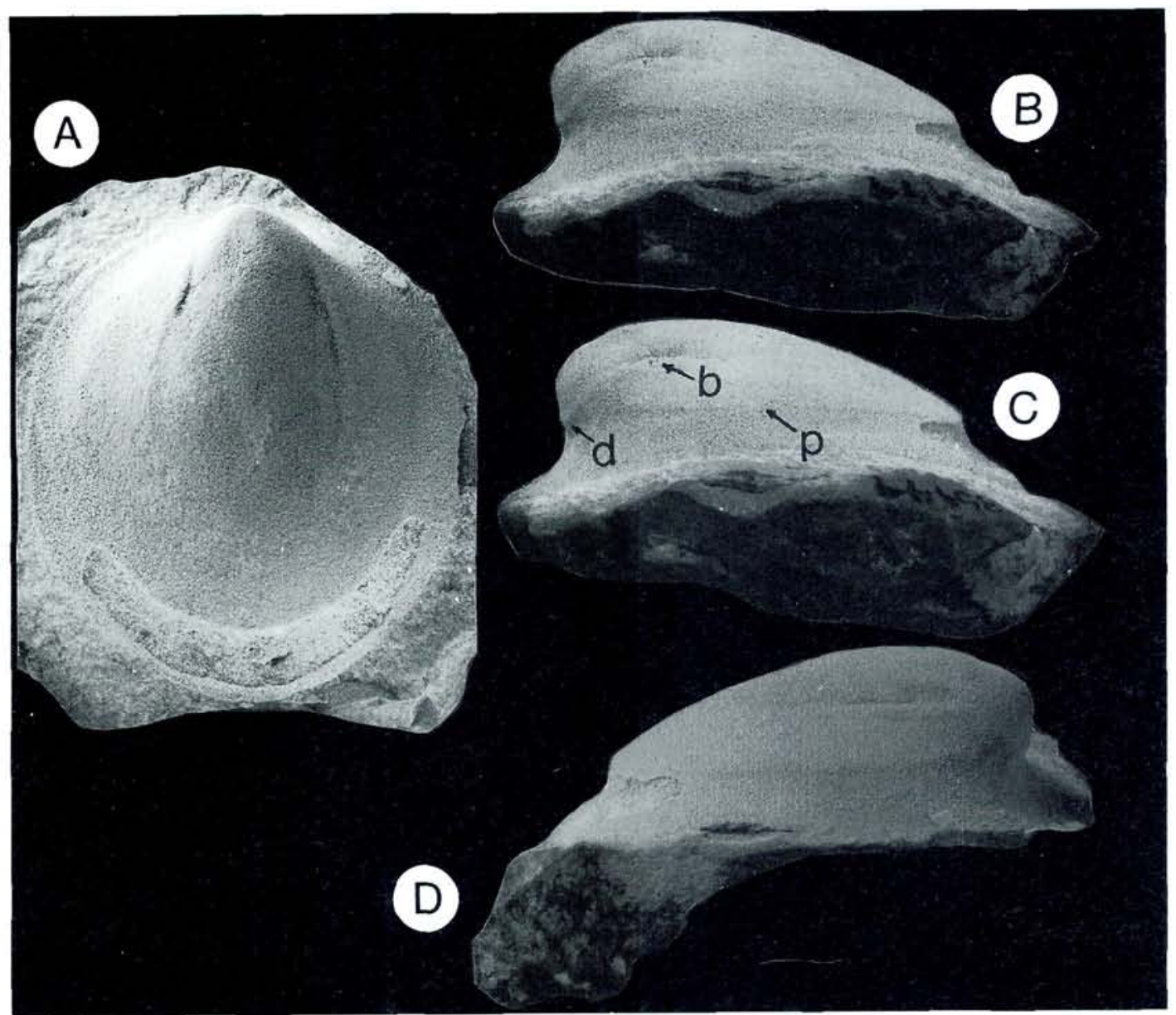

Fig. 4. Archinacella powersi Ulrich \& Scofield, 1897. As Fig. 3, but internal mould of the holotype showing the dorsal band interpreted as a muscle scar, X 2. A, dorsal view, note the abapical gap in the band. The broad crescentic structure at the abapical margin is of diagenetic origin. B, C, view of the left side showing the arched plane of the aperture and the dorsal band passing beneath the apex (b). An incipient sub-apical depression (d) is formed at the 8 junction of the muscle scar and the slightly angular lower margin of the pallial cavity (p). D, the right side.

istic of Guelphinacella is not present in Archinacella. An incipient structure can be detected in $A$. powersi where the muscle scar passes below the apex on the internal mould (Fig. 4) but this probably reflects the interference of the raised muscle scar and the lower margin of the supposed pallial cavity.

\section{Guelphinacella - gastropod or monoplacophoran?}

Discussion concerning the systematic position of Archinacella during the last three decades summarises arguments relevant to the interpretation of the morphologically similar Guelphinacella.

Classification of Archinacella. - Although originally described as a gastropod, the recognition of the Class Monoplacophora prompted Knight \& Yochelson $(1958,1960)$ to place Archinacella within an Order Archinacelloidea of the Monoplacophora. The apex in A. powersi was considered anterior; the U-shaped muscle scar band 
was continuous below this anterior apex and open toward the posterior. Horný $(1961 ; 1963 b$; 1965), in describing Bohemian faunas, maintained the order (in the form Order Archinacellida) as a constituent of the Class Monoplacophora, but assigned it to his new Sub-class Cyclomya together with the coiled cyrtonellids. The 'classic' monoplacophorans Pilina and Tryblidium were separated in the Sub-class Tergomya. It should be noted, however, that the concept of Archinacella employed by Horný embraced species in which the muscle band was continuous and not broken at the abapical margin, as in the type species.

Starobogatov (1970) refuted these assignments and considered Archinacella and the related genera Archinacellina Horný, 1961 and Archaeopraga Horný, 1963a to be gastropods. His opinion was later formalised by Golikov \& Starobogatov (1975) who recognised an Order Archinacellida within their gastropod Sub-class Cyclobranchia Cuvier, 1897 (In the classification proposed by Golikov \& Starobogatov, five subclasses of gastropods were recognised - Cyclobranchia, Scutibranchia, Pectinibranchia, Pulmonata and Opisthobranchia - in contrast to the more traditional tripartite division into Prosobranchia, Pulmonata and Opisthobranchia, cf. Cox, 1960). In Archinacella interpreted as a gastropod, the apex was thus considered posterior, with the gap in the muscle scar band lying anteriorly.

Runnegar \& Jell (1976) did not make use of Horný's Sub-classes Cyclomya and Tergomya but placed Archinacella together with Tryblidium and Pilina and a number of other genera in the single family (Tryblidiidae) within the monoplacophoran Order Tryblidiida.

Harper \& Rollins (1982) accepted Archinacella as a member of Horný's Cyclomya but concluded that members of the sub-class were actually gastropods rather than monoplacophorans; members of the sub-class Tergomya Horný, 1965 were considered to be the only true monoplacophorans. Harper \& Rollins (1982) did not discuss the conclusions of Starobogatov (1970) concerning the systematic position of Archinacella.

Yochelson (1988) described a new Middle Ordovician genus, Floripatella, and considered both it and Archinacella to be patellacean gastropods. After reviewing the philosophical background which prompted the monoplacophoran assignment of Knight \& Yochelson (1958), Yochelson (1988, p. 199) justified his current position by stating "unless a shell shows a multiple series of pairs of muscle scars it should be excluded from the Monoplacophora."

A majority of recent authors thus concludes that Archinacella should be interpreted as a gastropod, as originally proposed by Ulrich \& Scofield (1897), although the background for this conclusion varies from author to author.

Systematic position of Guelphinacella. - If the dorsal band in Guelphinacella does represent a muscle scar, then Guelphinacella should be interpreted as a gastropod invoking the arguments proposed by Yochelson (1988) in his discussion of Archinacella. Since the band is not preserved in the vicinity of the apex it can not be conclusively determined if Guelphinacella is a cyclomyan (as is Archinacella) or a tergomyan (as are Tryblidium and Pilina). Thus, it can not be interpreted as a gastropod (i.e., cyclomyan) with certainty, following the arguments applied to Archinacella by Starobogatov (1970), Golikov \& Starobogatov (1975) and Harper \& Rollins (1982). Following Horný (1965) and Runnegar \& Jell (1976), interpretation as tergomyan or cyclomyan would not effect placement within the Monoplacophora.

If the dorsal band is not interpreted as a muscle scar, but as a fluke of preservation, no basis exists for the interpretations presented above and Guelphinacella could equally well have been a gastropod or a monoplacophoran. In this case, however, interpretation of the sub-apical thickening as a parietal deposit analagous to the inner shelflike thickening of carinaropsinids or the lamella of Crepidula clearly suggests that Guelphinacella should be interpreted as a gastropod. This placement is followed here.

Acknowledgments. Tom Bolton is thanked for his kindness in connection with examination of the type of Guelphinacella canadense in the collections of the Geological Survey of Canada, Ottawa. Fred Collier kindly arranged loan of the types of Archinacella powersi from the U.S. National Museum of Natural History, Washington D.C. Publication is approved by the Geological Survey of Greenland. 


\section{Dansk sammendrag}

I nærværende arbejde beskrives Tryblidium Canadense Whiteaves, 1884 fra Guelph Formationen (Silur) i Ontario, Canada. Aftryk på stenkærnen diskuteres og sammenlignes med muskelaftryk i andre nedre palzozoiske bløddyr, specielt Archinacella powersi Ulrich \& Scofield, 1897 fra Ordovicium i U.S.A. Det konkluderes at $T$. canadense tilh $\emptyset$ rer en nye slagt, Guelphinacella (Gastropoda).

\section{References}

Boucot, A. J. 1975: Tryblidium thorsteinssoni; first North American occurrence of the Silurian monoplacophoran genus. Bull. geol. Surv. Canada 235, 1-3.

Cox, L. R. 1960: Gastropoda - general characteristics of Gastropoda. In: Moore, R. C. (ed.) Treatise on Invertebrate Paleontology part I, Mollusca 1, I84-I169. Lawrence: Univ. Kansas Press.

Golikov, A. N. \& Starobogatov, Y. I. 1975: Systematics of prosobranch gastropods. Malacologia 15(1), 185-232.

Harper, J. A. \& Rollins, H. B. 1982: Recognition of Monoplacophora and Gastropoda in the fossil record: a functional morphological look at the bellerophont controversy. Proc. IIIrd N. Am. Palaeont. Conv. 1, 227-232.

Horný, R. J. 1961: New genera of Bohemian Monoplacophora and patellid Gastropoda. Vestnik Ustred. Ust. Geol. 36, 299-302.

Horný, R. J. 1963a: Archaeopraga, a new problematic genus of monoplacophoran molluses from the Silurian of Bohemia. J. Paleont. 37, 1071-1073.

Horný, R. J. 1963b: Lower Paleozoic Monoplacophora and patellid Gastropoda (Mollusca) of Bohemia. Sbomik Ústred. Ust. Geol. odd. paleont. 28, 7-83.

Horný, R. J. 1965: Cyrtolites Conrad, 1838 and its position among the Monoplacophora (Mollusca). Sbornik Národ. Muz. Praze 21, B, 2, 57-70.

Knight, J. B. 1941: Paleozoic gastropod genotypes. Spec. Pap. geol. Soc. Am. 32, 510 pp.

Knight, J. B. 1952: Primitive fossil gastropods and their bearing on gastropod classification. Smithson. misc. Collns 111(3), $56 \mathrm{pp}$.

Knight J. B. \& Yochelson, E. L. 1958: A reconsideration of the Monoplacophora and the primitive Gastropoda. Proc. malac. Soc, London 33, 37-48.

Knight, J. B. \& Yochelson, E. L. 1960: Monoplacophora. In: Moore, R. C. (editor) Treatise on Invertebrate Paleontology part I. Mollusca 1, I77- 184. Lawrence: Univ. Kansas Press.
Lemche, H. \& Wingstrand, K. G. 1959: The anatomy of Neopilina galatheae Lemche, 1951. Galathea Rep. 3, 9-71.

Lindström, G. 1884: On the Silurian Gastropoda and Pteropoda of Gotland. Handl. Kungl. Svenska VetenskapsAkad. 19, 6, 250 pp.

Miller, S. A. 1889: North American geology and palaeontology for the use of amateurs, students, and scientists. Cincinnati. $664 \mathrm{pp}$.

Northrop, S. A. 1939: Paleontology and stratigraphy of the Silurian rocks of the Port Daniel-Black Cape Region, Gaspé. Spec. Pap. geol. Soc. Am. 21, 302 pp.

Peel, J. S. 1977: Relationship and internal structure of a new Pilina (Monoplacophora) from the Late Ordovician of Oklahoma. J. Paleont. 51, 116-122.

Poulsen, C. 1974: Silurian Pelecypoda, Monoplacophora, and Gastropoda from the reefy facies of the Offley Island Formation of Washington Land and Offley Island (Northwest Greenland). Biol. Skr. Dan. Vid. Selsk. 20, 7, 14 pp.

Runnegar, B. \& Jell, P. A. 1976: Australian Middle Cambrian molluscs and their bearing on early molluscan evolution. Alcheringa 1, 109-138.

Starobogatov, Y. I. 1970: K sistematike rannepaleozoiskikh Monoplacophora. Paleont. Zhur. 3, 6-17. [published in english: Systematics of Early Paleozoic Monoplacophora. Paleont. Jour. 1970, 3, 293-302].

Ulrich. E. O. \& Scofield, W. H. 1897: The kower Silurian Gastropoda of Minnesota. Geology of Minnesota Final Rept. 3, 2, 813-1081.

Wenz, W. 1940: Ursprung und frühe Stammesgeschichte der Gastropoden. Arch. Molluskenkunde 72, 1-10.

Wenz, W. 1938-1944: Gastropoda. Allgemeiner Teil und Prosobranchia. In: Schindewolf, O. H. (ed.) Handbüch der Palozoologie 6, 1639 pp.

Whiteaves, J. F. 1884: On some new, imperfectly characterised or previously unrecorded species of fossils from the Guelph formation of Ontario. Geol. Survey Canada, $\mathrm{Pa}$ laeozoic Fossils 3, 1-43.

Whiteaves, J. F. 1895: Revision of the fauna of the Guelph formation of Ontario, with description of new species. Geol. Survey Canada, Palaeozoic Fossils 3, 45-109.

Whiteaves, J. F. 1906: Revised list of the fossils of the Guelph formation of Ontario. Geol. Survey Canada, Palaeozoic Fossils 3, 313-325.

Wingstrand, K. G. 1985: On the anatomy and relationships of Recent Monoplacophora. Galathea Rep. 16, 7-44.

Yochelson, E. L. 1988: A new genus of Patellacea (Gastropoda) from the Middle Ordovician of Utah: the oldest known example of the superfamily. Mem. New Mexico Bur. Mines Min. Res. 44, 195-200. 